\title{
Besin İntoleransı ve Tanı Testleri
}

\author{
Sabiha Zeynep Aydenk Köseoğlu ${ }^{1 *}$ \\ ${ }^{1}$ İstanbul Sabahattin Zaim Üniversitesi, Sağlık Bilimleri Fakültesi, Beslenme ve Diyetetik Bölümü, İstanbul, Türkiye (ORCID: 0000-0001-7936-8462)
}

(İlk Geliş Tarihi 24 Ocak 2020 ve Kabul Tarihi 18 Mart 2020)

(DOI: $10.31590 /$ ejosat.679474)

\begin{abstract}
ATIF/REFERENCE: Köseoğlu, S. Z. A. (2020). Besin İntoleransı ve Tanı Testleri. Avrupa Bilim ve Teknoloji Dergisi, (18), 616-620.
$\ddot{O} \mathbf{z}$

Beslenme alanında yapılan son çalışmalarda, günlük tüketilen bazı besinlerin sağlığı bozması ve duyarlılık oluşturmasının yanı sıra yaşam kalitesini belirli açılardan ve değişik açılardan etkilediği saptanmıştır. Bu derleme insan sağlığını çok yakından ilgilendirip, büyük ölçüde yaşam kalitesini etkileyen besin intoleransı ve oluşturan faktörler, sonuçları ve intolerans bulgularının belirlenmesinde kullanılan testlerin uygulanma şekilleri, değerlendirilme özellikleri konusunda bilgi vermeyi amaçlamaktadır. Sürekli değişik şikayetler ile sağlık profesyonellerine başvuran kişilerde ilk olarak belirtiler ilaçlar yoluyla giderilmeye çalışılmış ve çözüme gidilemeyen vakalarda, bu sorunlar psikolojik sebeplere dayandırılmıştır. Ancak yapılan birçok araştırma, besin duyarlılığı ile meydana gelen sorunlarda, duyarlılığa sebep olan gıdaların diyetten uzaklaştırılması ile besin intoleransının yan etkilerinin azaldığı ve hatta tamamen yok olabildiğini göstermektedir. Bilimin gelişmesi ile doğal olarak gelişen besin intoleransına ilaveten kullanılan zirai atıklar, besin katkı ve boya maddeleri, renk vericiler, genetiği değiştirilmiş besinler kişilerde son yıllarda görülen besin duyarlılık etkilerinin artmasına neden olmakta ve ayrıca bu tür sorunlar toplumda refahı, yaşam kalitesini bozmakta ve ilaç harcamaları nedeniyle ülke ekonomisini negatif yönde etkilemektedir. Kişilerin hayatında bu denli önemli bir yere sahip olan besin intoleransının varlığını anlayabilmek ve oluşturduğu ve oluşturabileceği sorunlarla baş edebilmek için besin duyarlılığı testlerinin sağlık profesyonelleri tarafindan topluma tanıtılması ve bu testlere erişimin kolaylaştırılması büyük önem taşımaktadır.
\end{abstract}

Anahtar kelimeler: Besin intoleransı, yaşam kalitesi, besin intolerans testleri

\section{Food Intolerance and Diagnostic Tests}

\begin{abstract}
In recent nutrition field studies, it has been found that some foods consumed daily are health-damaging and create sensitivity, as well as affecting quality of life from certain angles and at different angles. This review aims to provide information about food intolerance, factors affecting the quality of life,results and methods of application of tests used in determination of intolerance findings. In people who apply to healthcare professionals with various complaints, the symptoms were tried to be resolved firstly, and in cases that could not be resolved, these problems were based on psychological causes. However, many studies have shown that the problems caused by food sensitivity, the removal of foods that cause sensitivity from the diet and the side effects of food intolerance can be reduced and even disappear completely. Agricultural wastes, nutrient additives and dyes, colorants, genetically modified foods used in addition to naturally occurring food intolerance with the development of science cause an increase in food sensitivity effects in people in recent years, and also such problems impair welfare, quality of life and drug expenditures. negatively affects the country's economy. In order to understand the existence of food intolerance, which has such an important place in people's life, and to cope with the problems it creates and may create, it is very important to introduce food sensitivity tests to the society and to facilitate access to these tests.
\end{abstract}

Keywords: Food intolerance, life quality, food intolerance tests

\footnotetext{
* Sorumlu Yazar: İstanbul Sabahattin Zaim Üniversitesi, Sağlık Bilimleri Fakültesi, Beslenme ve Diyetetik Bölümü, İstanbul, Türkiye, ORCID: 00000001-7936-8462, szaydenk@gmail.com
} 


\section{Giriş}

\section{Besin Duyarlılı̆g}

Besin duyarlılığı (besin intoleransı) bir besin ya da besin bileşeni tarafindan uyarılan vücudun gösterdiği olumsuz reaksiyonlardır. Bir sindirim sistemi yanıtı olup, her kişide farklı şekillerde ortaya çıkabilir. Yaklaşık olarak nüfusun \%60'ından fazlasında besin duyarlılığı olduğu düşünülmektedir (Wilson, 2010). Meydana gelen bu duyarlılık reaksiyonları sindirilemeyen veya emilemeyen besin ya da besin bileşenlerinin etkisiyle meydana gelmektedir. Besin intoleransları arasında en yaygın görüleni laktoz intoleransı, yani sütteki bir karbonhidrat türü olan laktozu sindirecek laktaz enziminin bulunmamasından doğan bir intoleranstır. Laktoz duyarlılığı dünyada yetişkin popülasyonun \%50'sinde ortaya çıkan ve en fazla bilinen besin duyarlılı̆̆ıdır (Yamada, Alpers ve Owyang, 2002).

Ayrıca bunun dışında bazı kişilerde tat artırıcılar (MSG) veya koruyucular (sülfit) gibi gıdalara eklenen bazı maddelere karşı duyarlılık görülebilmektedir (Ascia, 2010).

Günlük beslenmemizde yer alan besinler duyarlılık oluşturabilmektedir. Bitkiler yapısal olarak kabaca protein, yağ ve karbonhidratlardan oluşurlar. Ayrıntılı olarak incelendiğinde farklı grup bitkiler, farklı iklim koşulları ve ekolojik ortamda yetiştiklerinden dolayı kimyasal içerik açısından farklılıklar gösterirler. Yapılan bazı araştırmalara göre bazı bitkiler genelde hiç duyarlılık yapmazken bazıları da genel olarak duyarlılı̆̆a sebep olmaktadır (Uzunismail ve ark, 2012).

Bitkilerin kimyasal yapısını oluşturan yağ ve yağ asitleri, proteinler, aminoasitler, vitamin ve diğer farklı yapıların miktar ve çeşitlerine göre besinlerin çeşitli reaksiyonlarına sebep oldukları ya da olmadıkları düşünülmektedir (Kalyoncu, 1999). Karbonhidrat, protein ve lipit intoleransının temelini enzim yoksunluğu ya da eksikliği oluşturmaktadır. (Douglas, Gerald ve Beam, 1970; Tuula, Marteau ve Korpela, 2000). Bu doğuştan gelen bir problem olmakla beraber, yaşlanma ile ilgili olarak zamanla da ortaya çıkabilmektedir (Wilson, 2010).

Besin intoleransı bulunan bireyler uzun süre, sorunlarıyla nasıl baş edeceklerini bilemezler normal yaşam ve fonksiyonlarında sorun yaşayabilir, hatta bazı vakalar çalışamaz hale bile gelebilirler.

Besin duyarlılığı, şişmanlık, zayıflamada başarısızlık, migren, akne, sebebi anlaşılamayan ödem, gaz, şişkinlik, kabızlık, kronik yorgunluk, cilt sorunları (örn: sivilceler, kaşıntı, nörodermatit, kronik egzema vb.), romatizmal hastalıklar, astım, ishal, karın ağrıları, depresyon, uyku bölünmeleri, baş ağrısı, solunum sistemi hastalıkları, kronik farenjit, sürekli nezle, epigastrik ağrılar, ağızda yaralar, crohn hastalığı, irritable barsak sendromu, kronik burun akıntısı, sık grip olma, otistik spektrum bozukluğu, sedef hastalığı, ürtiker gibi birçok hastalığa yol açabilir (Wilson,2010).

\section{Besin Duyarlılığı ve Besin Alerjisi}

Besin intoleransı bulguları bireyden bireye değişkenlik gösterdiğinden hangi bileşenin bulgulardan sorumlu olduğunu belirlemenin olanağ 1 yoktur.

Ayrıca benzer reaksiyonlar görüldüğünden besin duyarlılığı bulguları besin alerjileri ile de karıştırılabilmektedir. Besin alerjisi, çocukları ve yetişkinleri etkileyen önemli bir halk sağlığı sorunudur ve son 2-3 yıl içinde yaygınlığı artmaktadır. Semptomlar hafif ile şiddetli arasında değişebilir ve aşırı durumlarda besin alerjisi, hayatı tehdit eden alerjik bir reaksiyon olan anafilaksiye yol açabilmektedir (Seth, Poowutikul, Pansare ve Kamat, 2020). Aynı zamanda, vücutta immün sistemde bazı reaksiyonları oluşturan ve çeşitli tanı testleriyle gözlemlenip, saptanan bir reaksiyondur. Buna karşılık genel kanı olarak besin duyarlılığı bağışıklık sistemini etkilememektedir (Öztürk ve Besler, 2006). Besin intoleransları sindirim sistemini, besin alerjileri ise immün sistemi içerir. İmmünglobulin $\mathrm{E}$ (IgE) antikorunun yol açtığı besin alerjisinin aksine, besin intoleransları (sülfit ve benzoat reaksiyonları hariç) yaşamı tehdit edebilecek anafilaksiye (ağır alerjik reaksiyonlar) neden olmaz. IgE aracılı olmayan besin alerjileri bazen besin intoleransları olarak adlandırılır, ancak bu koşullar bağışıklık sistemini içerir, bu yüzden bağışıklık sistemini içermeyen besin intoleranslarından farklıdırlar (Ascia, 2010).

\section{Besin İntoleransının Nedenleri}

Besin intoleransını oluşturan mekanizma, bir nedene değil birden fazla nedene bağlı olabilir. Yapılan tüm çalışmalar sonucunda besin intoleransının nedenleri gruplanmıştır.

\section{Toksik Etkiler}

Besinlerde doğal olarak yer alan veya kontaminasyon yoluyla besinlere geçen toksinlerin etkisiyle besin intoleransı oluşabilir. Örneğin; bazı patates türleri ve barbunya çiğ yenildiği takdirde, bu besinlerin içerdiği glukoalkoloidler sebebiyle gastrointestinal bulgular ortaya çıkabilir (Arıcan ve Hacımustafaoğlu, 2002).

Ayrıca, 1stakoz, karides, midye, yumurta akı ve çilek gibi besinler, mast hücrelerinden histamin salgılanmasına neden olur ve klinik belirtiler ortaya çıkar (Yakacaklı, Öneş, Akçakaya ve Ezer, 1983).

Bundan başka histamini doğal olarak içeren peynir, bazı şarap ve balık türleri (tuna ve uskumru gibi) de besin duyarlılığı oluşturabilirler (Arıcan ve Hacımustafaoğlu, 2002).

Besinlerin depolanması ve işleme tabi tutulması sırasında oluşan deoksiketon artıkları da histamin açığa çıkartarak intoleransa neden olabilirler (Yakacaklı ve ark., 1983). 


\section{Farmakolojik Etkiler}

Gıdalarda yer alan farmakolojik maddelerin etkisiyle besin duyarlılığı meydana gelebilir. Örneğin gidalara renk ve tat vermek ya da mikroorganizmaların üremelerini engellemek amacıyla eklenen katkı maddeleri, gıda intoleransına neden olabilir. Bu maddelerin en önemlileri; tartrazin, mono sodyum glutamat (MSG) ve sülfitlerdir. Bu katkı maddelerinden tartrazin, ürtiker yapabilir. Bunların dışında, et ve ürünlerinde antioksidan ve bakterisid olarak kullanılan sodyum nitritin, gastroenterit ve ürtikere sebep olabildiği de çalışmalarla gösterilmiştir (Arıcan ve Hacımustafaoğlu, 2002).

Tiramin, serotonin ve histamin gibi vazoaktif aminler, kişilerin bazılarında iyi bilinen migren stimülatörleridir. Doğal olarak ananas, muz, pişmiş et, sebze, kırmızı şarap, ahşap olgunlaşmış beyaz şarap, avokado, çikolata, narenciye ve olgun peynirlerde bulunur. Aminler, kapasitelerini arttırmak için doğrudan küçük kan damarlarında hareket edebilir. Bu yüzden bazı insanlarda deride kızarma, migren ve burun tıkanıklığını tetikleyebilir.

Salisilatlar, çok çeşitli bitkilerde, baharatlarda, meyve ve sebzelerde bulunan doğal aspirin benzeri bileşiklerdir. Salisilatlara verilen reaksiyonlar, yapay renklere ve koruyuculara verilen reaksiyonlardan daha yaygın olabilir. Aspirin, doğrudan derinin mast hücreleri üzerinde hareket ederek alerjiyi tetikleyebilir, bu nedenle aspirin gibi salisilatlar bazı insanlarda reaksiyonları daha da kötüleştirebilir.

İrritenler; kafein ve köri bazı kişilerde hazımsızlığı tetikleyebilen bağırsak tahriş edicidirler. Bu maddelere verilen reaksiyonların alerji nedeniyle olup olmadı̆̆ını anlamak önemlidir (Ascia, 2010).

\section{Enzim Eksiklikleri}

Enzim eksikliği bulunan kişilerde, bazı gıdalara karşı aşırı duyarlılık reaksiyonu meydana gelmektedir.

1. Aldehit dehidrogenaz eksikliği; alkol tolerans bozukluğuna (bulantı, kusma, taşikardi)

2. Glikoz-6-fosfat dehidrogenaz eksikliği: baklagillerin intoleransına (hemolitik anemi oluşumuna)

3. Laktaz eksikliği; laktoz intoleransına (malabsorpsiyon sendromuna, diyareye) neden olabilir (Arıcan Ö ve ark., 2002). İmmünolojik olmayan gıda intoleransı reaksiyonları çoğunlukla karbonhidrat sindirim bozukluğuna (ör: laktoz intoleransı, früktoz malabsorpsiyonu) dayanır ve nadiren öncelikle kronik ürtikerli hastalarda psödo alerjilere (ör: lezzet vericiler, boyalar, koruyucular tarafından oluşan ) bağlıdır (Kleine ve ark., 2016).

\section{Psikolojik Etkiler}

Kişilerin bazı besinlerden saplantı olarak nefret etmesi ve onları tüketmekten kaçınmaları besin duyarlılı̆̆ının sebebi olabilir. Bu tür kişiler, nefret ettikleri besini almaları halinde kusma vb. tepkilerde bulunabilirler (Arıcan ve Hacimustafaoğlu, 2002).

Sağlıklı ve yaşam kalitesi yönünden daha iyi bir gelecek için, besin intoleransı bulunan kişilerde duyarlılığın sebebi çeşitli tanı testleri kullanılarak saptanmalıdır. Tanı konulduktan sonra, uygun eliminasyon ve rotasyon diyetleri uygulanarak sağlıklı ve normal yaşam kalitesinde bir hayata sahip olmaları sağlanabilir. Ig E dışında diğer immünglobülinlerin alerjik reaksiyonlara benzer tepkiler vermesi, bu testlerin üreticileri ve alerji konusunda çalışan bilim insanlarını karşı karşıya getirmiştir.

Besin duyarlılığına bağlı intolerans şikayetleri yaşayan kişilerde, çeşitli besinlerin çıkartılmasıyla hazırlanan eliminasyon diyeti ile ilgili, mide ve sindirim sistemi şikayetleri yaşayan kişilerde besin duyarlılığının etkilerine ilişkin gıdaların kimyasal içerikleri ile ilgili birçok çalışma mevcuttur.

Bu çalışmalardan bazıları:

Food Elimination Based on IgG Antibodies in Irritable Bowel Syndrome: A Randomised Controlled Trial; 150 hasta ile yapılan bu çalışmada, IgG antikoru artışına neden olan gıdalar elimine edilerek 3 ay boyunca diyet uygulamıştır. Sonucunda enzyme-linked Immunosorbent assay (ELISA) testi ile IgG antikorunda belirli oranlarda düşüşler belirlenmiş ve şikâyetlerde azalmalar olmuştur (Atkinson, Sheldon, Shaath ve Whorwell, 2004).

Crohn Hastalığı, Colitis Ulcerosa ve Functional Dyspepsia, Irritable Bowel Syndrome örtüşmesi olan hastalarda Gıda-spesifik IgG antikorları; Bu çalışmanın amacı bazı gastrointestinal hastalıklarda gıda-spesifik IgG antikorlarını karşılaştırmaktır. Sonuç olarak değişik hastalıklarda gözlenen farklı IgG antikor yanıtında farklı immunolojik reaksiyonlar etkili olabilmektedir (Uzunismail, Özbakır ve Çağatay, 2011).

Food Intolerance and the Irritable Bowel Syndrome; Farklı cinsiyet, sosyal sınıf ve yaşlarda 200 hastaya uygulanan diyet sonrasında irritable bağırsak sendromunun yarattığı kötü etkilerin (karın ağrısı, şişkinlik, ishal gibi) azaldığı gözlemlenmiştir (Nanda, James ve Smith, 1989). İrritabl bağırsak sendromu (IBS) hastalarının yaklaşık \% 80' i, semptomlarının bir veya belirli gıda grubunu tükettikten sonra bulgularının tetiklendiğini bildirmektedir. Gluten, buğday ve ilgili proteinler (örn: amilaz-tripsin inhibitörleri ve fermente edilebilir oligo-di-mono-sakkaritler ve polioller (FODMAP' ler) en önemli IBS semptom tetikleyicisidir, ancak halen tek neden olarak kabul edilmemektedir (Soares, 2018).

Histamine and Histamine Intolerance; Histamin intoleransı ile ilgili bu çalışmada histamin intoleransına sebep olan gıdaların ve ilaçların diyetten çıkarılması ve kullanılmaması ile pozitif sonuçlar elde edileceği açıklanmıştır. Histamin intoleransı bulunan kişilerin histaminden fakir gidalarla beslenmeleri önerilmektedir (Maintz ve Novak, 2007).

Detection of IgE, IgG, IgA and IgM Antibodies Against Raw and Processed Food Antigens; Ham ve işlenmiş gıdalara karşı immünglobulin E, G, A ve M antikorları saptanmaya çalışılmıştır. Hastaların \%31'inde işlenmiş gıda antijenlerinin, çiğ gıda IgE antikor oranına göre 3-8 kat artmış olduğu saptanmıştır. Benzer şekilde IgG, IgA ve IgM antikorlarının genel olarak çiğ gıdalara oranla işlenmiş 


\section{European Journal of Science and Technology}

gıdalarda daha yüksek oranlarda olduğu saptanmıştır. İşlenmiş besin antijenlerine karşı yüksek seviyede antikor düzeyi yüksek serumlarda hemen hemen her test okside düşük dansiteli lipoprotein, miyelin bazlı protein, AGE insan serumu albümini ve AGE hemoglobine karşı çok yüksek seviyede antikor görülmüştür (Vojdani, 2009).

Migraine and Food Intolerance: A controlled study in pediatric patients; Migren hastalığı ile ilgili birçok çalışma vardır. Migren ağrılarının intoleransa bağlı olup olmadığı ve belli grup besinler ilave edilerek oluşturulacak diyetlerle ağrıların azalıp azalmayacağı ile ilgili çocuklarda ve yetişkinlerde birçok çalışmalar yapılmıştır. Birkaç çalışmada istatistiksel olarak anlamlı sonuçların elde edilemediğinden söz edilse de genel olarak diyetin uygulanması ile şikayetlerin azaldığı bildirilmiştir. Bu makalede de kakao, muz, yumurta ve findığın özellikle migreni tetiklediği belirtilmiştir (Guariso ve ark., 1993). Yapılan daha ileri çalışmalarda, migreni tetikleyen yiyecek, içecek ve katkı maddelerinin listesi; peynir, çikolata, narenciye, sosisli sandviç, monosodyum glutamat, aspartam, yağlı yiyecekler, dondurma, kafein yoksunluğu ve alkollü içecekleri, özellikle kırmızı şarap ve birayı içermektedir (Millichap ve Yee, 2003).

Advers Reactions to Food Constituents: Allergy, intolerance and autoimmunity; Çölyak hastalığının olumsuz etkilerinin intoleransı yapan gıdaların diyetten çıkarılması ile intolerans riskinin azaltılacağı anlatılmaktadır. İntolerans sorunu olan kişilere özel, intolerans yapan kimyasalların işlenmiş hazır gıdalardan çıkarılarak, riskin azaltılabileceği öngörülmüştür. Bunun dışında hazır paketlenmiş gıdaların ambalajlarında, özellikle de bebek mamalarında gıda içeriklerinin ayrıntılı ve eksiksiz biçimde yazılması gerektiğine dikkat çekilmiştir (Kitts ve ark., 1997).

Alterations of food antigen-specific serum immunoglobulins $\mathrm{G}$ and $\mathrm{E}$ in patients with irritable bowel syndrome and functional dyspepsia; Sağlıklı insanlarla irritable bağırsak sendromlu hastalar yumurta ve soya gibi IgG antikorunu tetikleyen gidalarla beslenmiş̧tir. Çalışma sonucunda irritable barsak sendromlu kişilerde IgG antikorları titrelerinde önemli bir artış göstermiştir (Zuo ve ark., 2007).

İncelenen bu çalışmalarda çeşitli gıdaların insanlar üzerinde intolerans yaparak çeşitli semptomlara sebep oldukları açıklanmıştır. Kişilerde uygulanan farklı diyetler sonrası intolerans etkilerinin azaldığ ya da ortadan kalktı̆̆ tespit edilmiş̧ir.

İsveç’teki Karolinska Enstitüsü ise daha sonra geliştirdiği immunoassay test sistemi ile, alerjen spesifik IgE' leri kantitatif olarak ölçümlemeyi başarmıştır. Bu çalışmalardan sonra IgE yapılarının alerji patogenezindeki önemi daha fazla ortaya çıkmıştır.

Besin yan tesirleri şeklinde belirtilen ve alerjik olmamasına karşın, bağırsaktan emilimi ile, besin spesifik IgG'nin fazla salınımına sebep olabilen antijenik yapıların kişiler üzerinde verdiği reaksiyonlar ancak eliminasyon diyetleri uygulanarak tedavi edilebilmektedir. Bir taraftan da özellikle diyetisyenler için, intolerans testleri adı altında çalışılan gıda spesifik IgG izotiplerinin kantitatif ölçümleri tıbbi beslenme tedavisi programlarının hazırlanmasında esas oluşturmaktadır.

Besin intolerans testlerinde son zamanlarda gelişen teknolojiler ışığında yapılan farklı uygulamalar, konunun uzmanları arasında bir ikileme neden olmuştur.

İkilem oluşturan sorular: Gıda spesifik antijenleri olarak gıda spesifik Total IgG testlerini mi, yoksa gıda spesifik IgG4 fraksiyonunu inceleyen testleri yapmak mı daha doğru olur? şeklindedir (Van Der Zee, Van Swieten ve Aalberse,1986).

\section{Uygulanan Tanı Testleri}

ALCAT test sistemi 80'li yılların başında bu amaç için kullanılan bir test sistemi idi. Tekrarlanabilir olmaması ve test süresinin uzunluğu zaman içinde bu testin özelliğini kaybetmesine neden olmuştur.

LEAP MRT testi hastaların lenfositlerini alerjen maddelerle inkübe ederek, yapısal özelliklerinin değişmesini öngörmektedir. Sonuç olarak hücre sayımı yapılarak yapıları tepkime sonucu büyüyen hücreler üzerinden alerji tepkimesini ölçmektedir. ALCAT grubundan ayrılan bilim adamlarının uygulamasını gerçekleştirdikleri bu test yöntemi de zamanımızda ilkel kalmış ve tekrarlanabilirliği çok az bir yöntem olarak çok sık kullanılmamaktadır.

ELISA sistemlerinin yaygınlaşması ile, gıda alerji ve intoleransı testlerinde bu sistemlerin kullanımı yaygınlaşmışı̧r. İmmünglobülin izotiplerinin kantitatif ölçümlerine de izin vermesi ile ELISA yöntemini kullanan test sistemleri, tanı için en çok kullanılan yöntemler olmuştur. Bu test sistemi ile test süreleri 2-3 saate inmiş ve testlerin tekrarlanabilirliği en üst düzeylere ulaşmıştır. $\mathrm{Bu}$ test sisteminde hastadan damardan kan alınması ve çalışma sistemindeki hata oluşturabilecek süreçler teknolojiyi başka testler aramaya götürmüştür.

MICROARRAY - ELISA yöntemi en son geliştirilmiş gıda alerji ve intolerans test sistemidir. Hastanın parmağından alınan bir kan damlası ile 200'den fazla gida spesifik İmmünglobülin parametresine bakabilen bu test sistemi Microplate'ler kullanmak suretiyle daha küçük hacimlerde testi gerçekleştirerek, olası interferans etkilerini minimuma indirmeyi başarmıştır. Bu test çok düşük düzeylerdeki immünglobülin izotiplerinin belirleyebildiği için, geçici intolerans (temporary) ile kalıcı (permanent) intolerans hakkında bilgi vermektedir. Örneğin daha önce uygulanan testlerde 30 tane gıdadan uzak durulması söylenmesine rağmen aynı hasta için microarray-elisa yöntemi ile bu sayı 4-5 'e kadar inebilmektedir. (Allergy US- All you need about alllergies and food intolerance allergyus.com/food-intolerance-tests-in-usa/2015)

Eğer kişinin hastalığının temelinde yatan, besin alerjisi ise, gıda spesifik Ig E parametrelerinin seviyesini kantitatif olarak değerlendirmek ve buna bağlı olarak önlemini almak tedavinin esasını oluşturmaktadır.Altta yatan neden besin intoleransı ise genellikle IgG parametresinin alt gruplarının (G1, G2, G3, G4) etkisinin olabileceği ve besinin alınıp, sindirilmesinden sonra, besinin içerdiği bazı yapıların veya üretim aşamasında kullanılan gıda katkı, gıda boyası vb. lerin sebep oldukları reaksiyonlardır. 


\section{Avrupa Bilim ve Teknoloji Dergisi}

Kişide hiçbir besine alerji bulunmamasına rağmen bazı gıdaları tüketiminin arkasından sonra midede distansiyon, aşırı gaz, karın ağrısı, karın yanması, baş ağrısı, migren atakları gibi oluşan yan etkilerinin nedenlerini anlayabilmek için besin intolerans testlerinin yapılması ve gıdaya spesifik Ig G (total) kan düzeylerinin ölçülmesi son yıllarda en uygun yöntem olarak ele alınmaktadır.

Besin duyarlılığı testleri son yıllarda, özellikle beslenme uzmanları tarafindan uygulanan ve en çok aranılan testler arasında kabul edilmektedir. 1956'da Black'in lökosit yapıları üzerinden bulduğu test yöntemi yolu ile araştırılmaya başlanan gıdaya özgü antijenik etkiler gelişerek, özellikle son yıllarda uygulanan Microarray test sistemleri ile birlikte daha güvenli ve tekrarlanabilir sonuçlar üretilmeye başlanmıştır.

\section{Sonuç}

İnsan sağlığı ve yaşam kalitesini olumsuz olarak etkileyen besin intoleranslarının belirlenmesinde rol alan besin duyarlılığı testlerinin kullanılması, besin intoleransının oluşturduğu sorunların hangi besin veya besin grubundan kaynaklandığının belirlenmesinde ve dolayısıyla sorunların azaltılmasında ve tedavisinde tıpta büyük bir çı̆̆ı̆ açmaktadır.

Son yıllarda, DNA, RNA ve genlerin üzerine yapılan araştırmalarda kullanılan microarray test metodolojisinin besin intoleransı uygulamalarında kullanılması ile daha güvenilir ve sonuçlar elde edilmesine olanak tanınmıştır. Bu teknolojiden önce var olan ve uygulanan testlerden edinilen değerlerin fazla sayıda olması, kişilerin günlük beslenme düzenlerinde yer alan ve elimine etmeleri gereken besinlerin sayısının fazla olmasına neden olmakta olup, kişilerin beslenme planlarının yapılmasında zorluk çıkarmakta ve yeni ve son zamanlarda kullanılmaya başlayan teknoloji ile ise testin sonuçları sadece birkaç besinle sınırlanmakta ve kişilerin beslenme programlarını uygulamalarını kolaylaştırmaktadır.

\section{Kaynakça}

Allergy US- All you need about alllergies and food intolerance - allergyus.com/food-intolerance-tests-in-usa/2015.

Arıcan, Ö., Hacımustafaoğlu, O.Y., (2002). Besin Allerjisi. Kartal Eğitim ve Araştırma Hastanesi Tıp Dergisi, 2: 142-146.

ASCIA, (2010). The Australasian Society of Clinical Immunology and Allergy (ASCIA) is the peak professional body of Clinical Immunologists and Allergists in Australia and New Zealand. www.allergy.org.au.

Atkinson, W., Sheldon, T. A., Shaath, N. ve Whorwell, P. J. (2004). Food Elimination Based on IgG Antibodies in Irritable Bowel Syndrome: a Randomised Controlled Trial. Gut. 53:1459-1464.

Douglas, C., Gerald, G., Bram, R. (1970). Immunochemical Studies of Selected Subjects With Wheat Intolerance. Division of Immunochemistry and Allergy, 6, 333-346. Canada.

Guariso, G., Bertoli, S., Cernetti, R., Battistella, P.A., Setari, M., Zacchello, F.(1993). Food and Headache Attacks. A Comparison of Patients with Migraine and Tension-Type Headache. Panminerva Med. 44(1):27-31.

Kalyoncu, F.A, (1999). Bronș Astması ve Allerji Hastalıkları, Güneș Kitapevi, Ankara.

Kitts, D., Yuan, Y., Joneja, J., Scott, F., Szilagyi, A., Amiot, J., Zarkadas, M., Can, J., (1997) Advers Reactions to Food Constituents: Allergy, Intolerance and Autoimmunity. Can J Physiol Pharmacol. 75 (4) : 241 - 54.

Kleine-Tebbe, J, Waßmann-Otto, A, Mönnikes, H., (2016). Food Allergy and Intolerance: Distinction, Definitions and Delimitation Bundesgesundheitsblatt Gesundheitsforschung Gesundheitsschutz. 2016 Jun;59(6):705-22. Doi: 10.1007/s00103-016-2356-1 https://www.ncbi.nlm.nih.gov/pubmed/27215624.

Maintz, L., Novak, N., (2007). Histamine and Histamine Intolerance. Am J. Nutr. 85:1185- 96.

Millichap, J.G., Yee, M.M., (2003) The diet factor in pediatric and adolescent migraine.

Pediatr Neurol. 28(1):9-15.

Nanda, R., James, R, Smith, H., (1989). Food Intolerance and The Irritable Bowel Syndrome. Pubmed 30:1099-104.

Öztürk, M., Besler, T., (2006). Besin Alerjileri. Sağlık Bakanlığı. Sinem Matbaacılık Ankara.

Seth, D., Poowutikul, P., Pansare, M., Kamat, D., (2020).Food Allergy: A Review. Pediatr Ann 1;49(1):e50-e58. doi: 10.3928/19382359-20191206-01.

Soares, R.L.S., (2018) Irritable Bowel Syndrome, Food Intolerance And Non- Celiac Gluten Sensitıvity. A New Clinical Challenge. Arq Gastroenterol. 55(4):417-422. doi: 10.1590/S0004-2803.201800000-88.

Tuula, H. V., Marteau, P., Korpela, R. (2000). Lactose Intolerance Journal of the American College of Nutrition, p:165 -175.

Uzunismail, H., Özbakır, F., Çağatay, P., (2011). Crohn Hastalığı, Ülseratif Koliti ve Fonksiyonel Dispepsi İrritabl Bağırsak Sendromu Örtüşmesi Olan Hastalarda Gıda-Spesifik IgG Antikorları. Poser. Gastroentoloji Derneği Kongre Yayını. Antalya.

Uzunismail, H., Cengiz, M., Uzun, H., Özbakir, F., Göksel, S., Demirdağ, F., Can, G., Balcı, H., (2012). The Effects of Provocation By Foods With Raised IgG Antibodies and Additives on the Course of Crohn's Disease: A Pilot Study. Turk J Gastroenterol. 23(1):19 $-27$.

Van Der Zee, J.S., Van Swieten, P., Aalberse, R.C., (1986). Inhibition of complement activation by IgG4 antibodies.Clin Exp Immunol. 64:415-22.

Vojdani, A. (2009). Detection of IgE, IgG, IgA and IgM Antibodies Against Raw and Processed Food Antigens. Nutr Metab (Lond). : 22.

Wilson, L., ( 2010). Food Sensitivities or Intolerance, The Center for Development.

Yakacaklı, S., Öneş, Ü., Akçakaya, N., Ezer, G.. (1983). Çocuklarda besin allerjileri. I. Allerjik Hastalıklar Sempozyumu., 30-38.

Yamada, T., Alpers, D.H., Owyang, C.(2002). Handbook of gastroenterology. p:402- 418.

Zuo, X.L., Li ,Y.Q., Li, W.J., Guo, Y.T., Lu, X.F., Li, J.M. ve Desmond, P.V. (2007). Alterations of Food Antigen-specific Serum Immunoglobulins $\mathrm{G}$ and $\mathrm{E}$ in Patients With Irritable Bowel Syndrome and Functional Dyspepsia. Journal Compilation Blackwell. 37, 823-830. Australia.

https://www.allergy.org.au/patients/food-other-adverse-reactions/food-intolerance Erişim:29.12.2019

e-ISSN: 2148-2683 